\title{
Griseusin D, a New Pyranonaphthoquinone Derivative from a Alkaphilic Nocardiopsis sp.
}

\author{
Yi-Qing Li, Ming-Gang Li, Wei Li, Jiang-Yuan Zhao, Zhang-Gui Ding, Xiao-Long Cui, \\ Meng-Liang Wen
}

Received: August 29, 2007 / Accepted: December 12, 2007

(C) Japan Antibiotics Research Association

\begin{abstract}
A new pyranonaphthoquinone antibiotic, griseusin D (1) was isolated from the cultural fluid of the alkaphilic Nocardiopsis sp. The structure was determined as 5'-one-4-hydroxy-12-methoxygriseusin by spectroscopic methods, comparison with reported data and single-crystal $\mathrm{X}$-ray analysis. $\mathbf{1}$ displayed strong cytotoxicity against human leukemia cells (HL60) and modest cytotoxicity against human lung adenocarcinoma cell lines (AGZY) with $\mathrm{IC}_{50}$ values of 0.23 and $19.6 \mu \mathrm{g} / \mathrm{ml}$, respectively. It also exhibited weak antifungal activity against Alternaria alternate with MIC of $140 \mu \mathrm{g} / \mathrm{ml}$.
\end{abstract}

Keywords pyranonaphthoquinone, griseusin D, alkaphilic Nocardiopsis sp.

Pyranonaphthoquinone antibiotics isolated from various strains of bacteria and fungi have been shown to exhibit activity against a variety of Gram-positive bacteria, pathogenic fungi and yeasts, as well as exhibiting antiviral activity [1]. As unique members within the family of pyranonaphthoquinone antibiotics, griseusins $\mathrm{A}, \mathrm{B}, \mathrm{C}$ and their derivatives have been isolated from the cultures of Streptomyces griseus K-63 [2 4], S. griseus MJ361-48F3 [5], Actinomycete strain MJ932-SF3 [6] and Penicillium sp. [7].

M.-L. Wen (Corresponding author), Y.-Q. Li, M.-G. Li, W. Li, J.-Y. Zhao, Z.-G. Ding, X.-L. Cui: Laboratory for Conservation and Utilization of Bio-resources, Key Laboratory of Medicinal Chemistry for Natural Resources, Ministry of Education, Yunnan Institute of Microbiology, Yunnan University, Kunming, Yunnan 650091, PR China, E-mail: mlwen@ynu.edu.cn
In the course of our searching for novel anticancer agent, we have isolated a new antibiotic, griseusin D (1, Fig. 1), from the culture of alkaphilic Nocardiopsis sp. YIM 80133, which was isolated from soil sample collected from Qinghai Province, China. In this paper, we report the fermentation, isolation, structure elucidation and cytotoxicity of 1 .

Fermentation studies of the culture YIM 80133 were carried out in shake flasks. Stock cultures were maintained as frozen whole broths as $-80^{\circ} \mathrm{C}$ in a final concentration of $10 \%$ glycerol. The germination medium contained glucose $4.0 \mathrm{~g}$, yeast extract $4.0 \mathrm{~g}$, malt extract $5.0 \mathrm{~g}$, multiple vitamins solution $5.0 \mathrm{ml}$, and trace element solution $1.0 \mathrm{ml}$ per liter. The $\mathrm{pH}$ was 7.2 with no adjustment. A $500-\mathrm{ml}$ Erlenmeyer flask containing $100 \mathrm{ml}$ of this medium was inoculated with $3.0 \mathrm{ml}$ of the stock culture. The flasks were incubated at $28^{\circ} \mathrm{C}$ on a rotary shaker at $280 \mathrm{rpm}$ for 72 hours.

This germination $(30 \mathrm{ml})$ was used to inoculate the fermentation medium. The fermentation was carried out in a 500-ml Erlenmeyer flask containing $100 \mathrm{ml}$ of fermentation medium. The fermentation media used contained soybean flour $20 \mathrm{~g}$, and mannitol $20 \mathrm{~g}$ per liter.

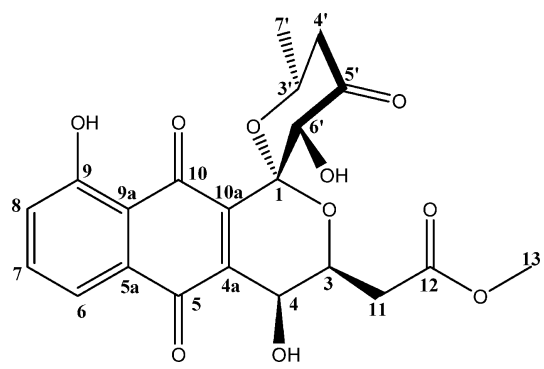

Fig. 1 Structure of griseusin D (1). 


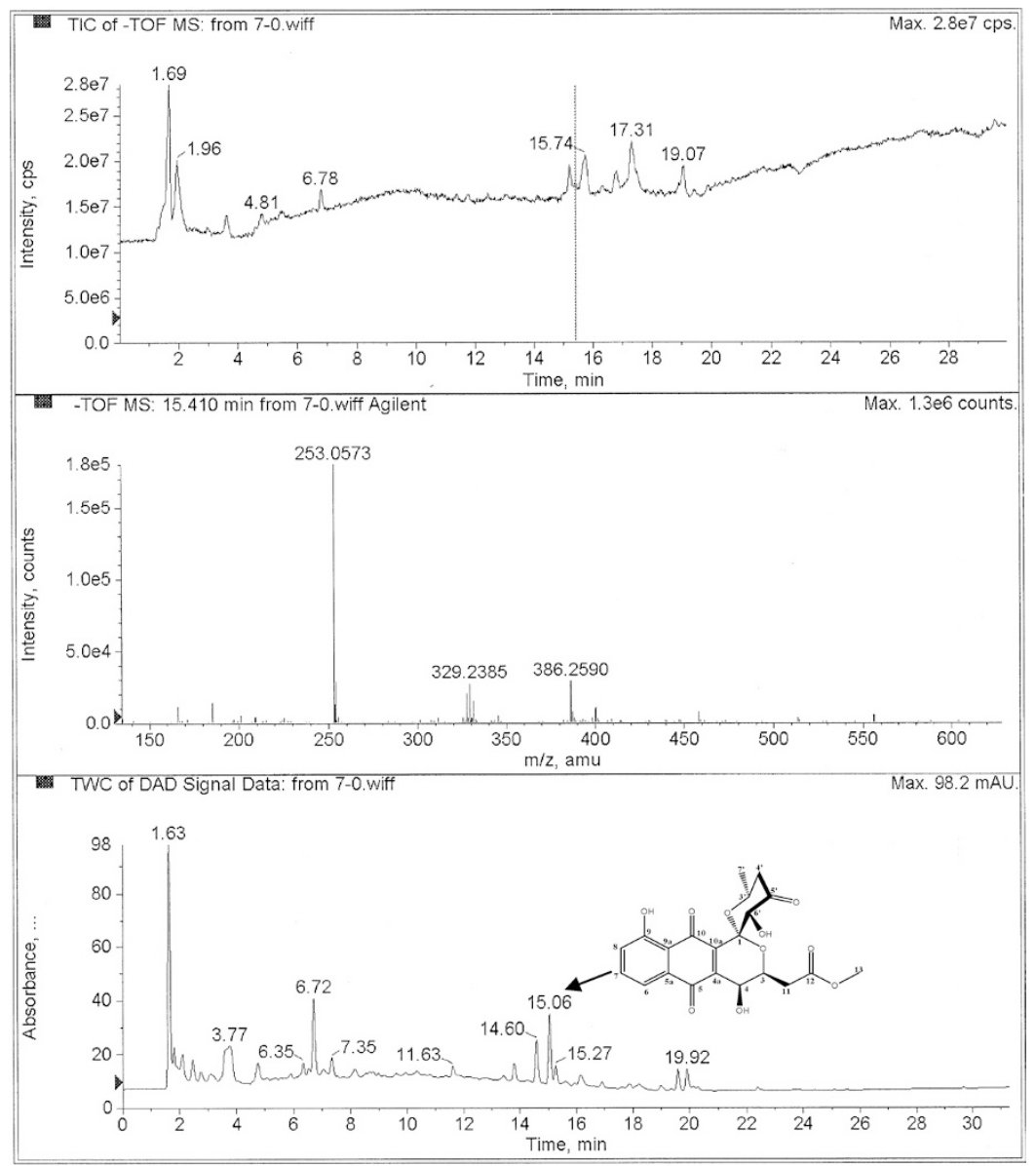

Fig. 2 LC-MS analysis of filtrate of fermentation broth of YIM 80133.

Peak at $\mathrm{Rt}=15.06$ minutes in LC and its molecular ion $\mathrm{m} / \mathrm{z} 431.1025[\mathrm{M}-\mathrm{H}]^{-}$in $-\mathrm{TOF}$ MS verified that the griseusin $\mathrm{D}$ was present in the culture before exposure to $\mathrm{MeOH}$. The filtrate was concentrated by 10 times in volume at $40^{\circ} \mathrm{C}$ in vacuo and then subjected for LC-MS analysis. LC Condition: 1. Column: Waters XTerra MS C18, $3.5 \mu \mathrm{m}, 3.0 \times 150 \mathrm{~mm}$. 2. Mobile Phase (Gradient): Acetonitrile : Water $=0: 100$ to 100 : 0.3. Time: 30 minutes. 4. Flow rate: $0.7 \mathrm{ml} / \mathrm{minute}$. 5. Temperature: $30^{\circ} \mathrm{C}$. 6.Wavelength: $254 \mathrm{~nm}$.

The $\mathrm{pH}$ was adjusted to 9.5 with $1 \mathrm{M} \mathrm{NaOH}$. The flasks were incubated at $28^{\circ} \mathrm{C}$ on a rotary shaker at $280 \mathrm{rpm}$ for 120 hours.

The completed fermentation broth (30 liters) was separated into filtrate and mycelium by centrifugation. LCMS analysis of filtrate $(\mathrm{pH}$ 6.58) confirmed that the griseusin D was present in the culture (Figs. 2 and 3). The culture filtrate was absorbed onto the polymeric resin Amberlite XAD-16 (8.0 liters, Rohm \& Hass, France). The salt and high molecular materials were washed out with water followed by $50 \%$ aq $\mathrm{MeOH}$ (8.0 liters each). Then, other absorbed organic material was eluted with 8.0 liters $70 \%$ aq $\mathrm{MeOH}$, and finally material was eluted with $100 \%$ $\mathrm{MeOH}$ to yield $13 \mathrm{~g}$ of dried material after removing solvent in vacuo. The organic material of the $100 \% \mathrm{MeOH}$ fraction was purified by column chromatography on: (1) silica gel $\left(\mathrm{CHCl}_{3}-\mathrm{MeOH}\right.$ gradient $)$, (2) Sephadex LH-20
$(\mathrm{MeOH})$, and by (3) preparative HPLC (Alltech Econosphere $\mathrm{C} 1810 \mu \mathrm{m}, 22 \times 250 \mathrm{~mm}$ i.d., $\mathrm{MeOH}-\mathrm{H}_{2} \mathrm{O}$ gradient, $10 \mathrm{ml} /$ minute) to afford $\mathbf{1}(80.0 \mathrm{mg})$.

The structure of $\mathbf{1}$ was mainly elucidated by extensive 1D and 2D NMR data analysis. In the ${ }^{1} \mathrm{H}-\mathrm{NMR}$ spectrum, a total of 17 carbon-attached protons were counted. One methyl, one methoxy, two methylene, and four oxygenbearing methine signals were observed in aliphatic region, and three resonances were observed in the olefinic/aromatic region. In the ${ }^{13} \mathrm{C}$-NMR spectrum, 21 carbon signals were detected, in which one cyclohexanone carbonyl group (C$5^{\prime}, \delta$ 203.7), two conjugated ketone functionalities (C-5, $\delta$ $182.0 ; \mathrm{C}-10, \delta 187.8)$, and one ester carbonyl group (C-12, $\delta$ 171.0) were identified. The molecular ion $\mathrm{m} / \mathrm{z}$ 455.0999, $[\mathrm{M}+\mathrm{Na}]^{+}$was observed on an ESI-MS instrument, and therefore the molecular formula of $\mathbf{1}$ was calculated as $\mathrm{C}_{21} \mathrm{H}_{20} \mathrm{O}_{10}$. Thus, three hydroxyl groups were proposed to 


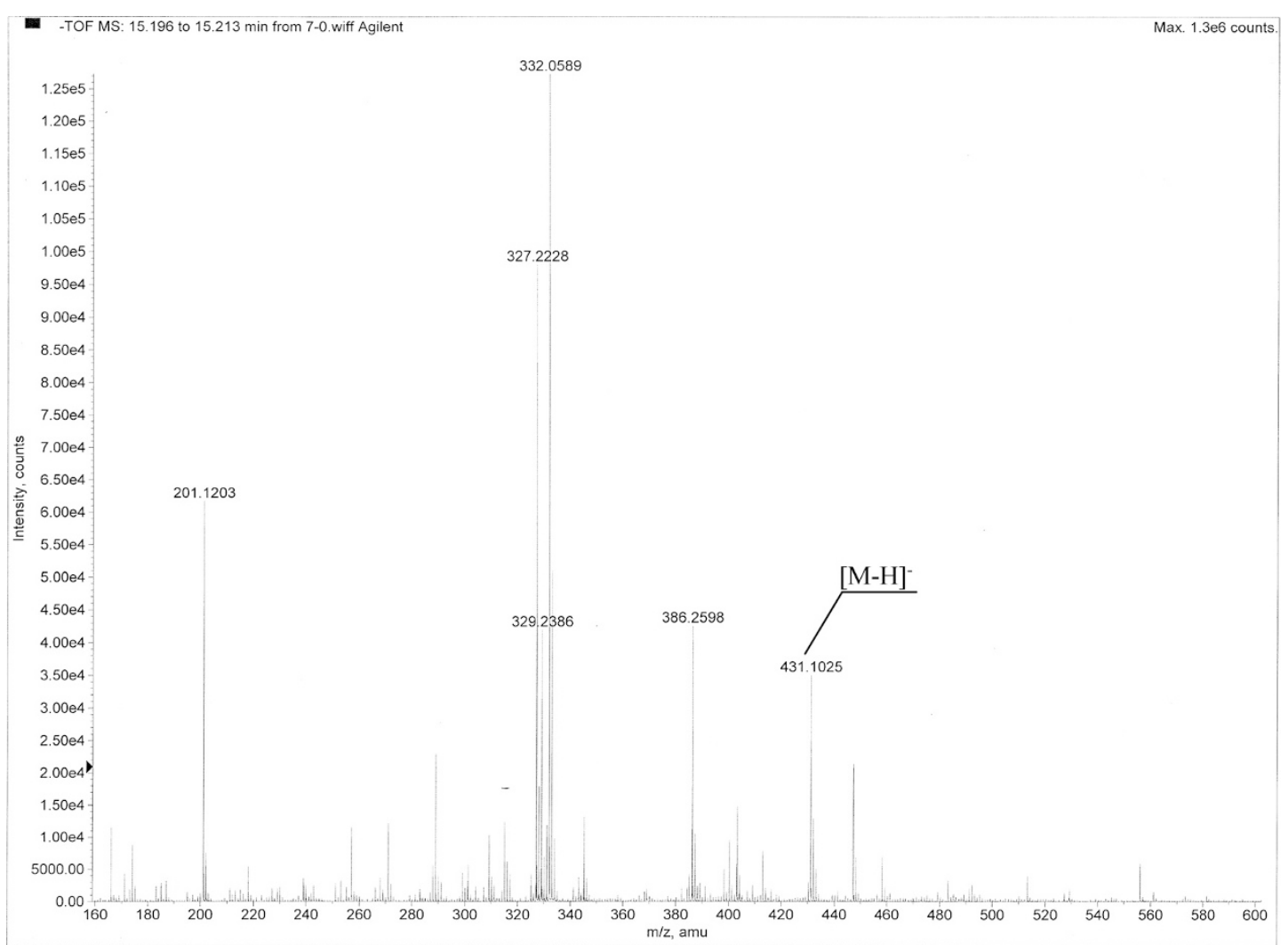

Fig. 3 Magnified spectrum of -TOF MS for 15.196 to 15.213 minutes of filtrate of fermentation broth of YIM 80133.

be presented in the molecule. The ${ }^{1} \mathrm{H}-\mathrm{NMR}(\mathrm{H}-6,7.57, \mathrm{~d}$, $J=7.4 \mathrm{~Hz} ; \mathrm{H}-7,7.78, \mathrm{t}, J=8.1,7.4 \mathrm{~Hz} ; \mathrm{H}-8,7.38$, d, $J=8.1 \mathrm{~Hz}$ ) and ${ }^{1} \mathrm{H}-{ }^{1} \mathrm{H}$ COSY correlations from $\mathrm{H}-6$ through $\mathrm{H}-8$ revealed the presence of one trisubstituted benzene in the molecule. Based on HMBC correlations from H-8 $(\delta$ $7.38)$ to $\mathrm{C}-9 \mathrm{a}(\delta 114.9)$ and $\mathrm{C}-6(\delta 118.5), \mathrm{H}-7(\delta$ 7.78) to C-5a $(\delta 131.5)$ and C-9 $(\delta 160.5), \mathrm{H}-6(\delta 7.57)$ to $\mathrm{C}-10(\delta$ $187.8), \mathrm{C}-9 \mathrm{a}(\delta 114.9), \mathrm{C}-8(\delta 124.6), \mathrm{C}-5(\delta 182.0)$ and $\mathrm{C}-4 \mathrm{a}(\delta 136.8)$, and $9-\mathrm{OH}(\delta 11.23)$ to $\mathrm{C}-9 \mathrm{a}(\delta 114.9), \mathrm{C}-9$ $(\delta 160.5)$ and $\mathrm{C}-8(\delta$ 124.6), the structure of fragment $\mathrm{A}$ was proposed (Fig. 4). Based on ${ }^{1} \mathrm{H}-{ }^{1} \mathrm{H}$ COSY correlations from H-7' $(\delta 1.25)$ through $\mathrm{H}-3^{\prime}(\delta 4.28)$ and $\mathrm{H}-4^{\prime}(\delta 2.59$, $2.42)$, and from H-11 $(\delta 2.81,2.69)$ through H-3 $(\delta 4.31)$, $\mathrm{H}-4(\delta$ 4.45) and 4-OH ( $\delta$ 4.98); as well as HMBC relations form $\mathrm{H}-7^{\prime}(\delta 1.25)$ to $\mathrm{C}-4^{\prime}(\delta$ 47.7) and C-5' $(\delta$ $203.7), \mathrm{H}-4^{\prime}(\delta 2.59,2.42)$ to $\mathrm{C}-7^{\prime}(\delta 21.1), \mathrm{C}-6^{\prime}(\delta 76.3)$ and $\mathrm{C}-5^{\prime}\left(\delta\right.$ 203.7), $\mathrm{H}-6^{\prime}\left(\delta\right.$ 5.13) to $\mathrm{C}-1^{\prime}(\delta$ 100.2), H-13 $(\delta 3.62)$ to $\mathrm{C}-12(\delta 171.0), \mathrm{H}-11(\delta 3.62)$ to $\mathrm{C}-12(\delta 171.0)$ and $\mathrm{C}-4(\delta 58.5), \mathrm{H}-3(\delta 4.31)$ to $\mathrm{C}-12(\delta 171.0)$ and $\mathrm{H}-4$ $(\delta 4.45)$ to $\mathrm{C}-10 \mathrm{a}(\delta 145.3)$, the structure of fragment $\mathrm{B}$ was proposed (Fig. 4). Comparisons of the ${ }^{1} \mathrm{H}-,{ }^{13} \mathrm{C}-\mathrm{NMR}$ data and HMBC spectra (Fig. 4) of 1 and 4'-deacetyl-(-)griseusin B [6] showed that the compound $\mathbf{1}$ is very similar to the 4 '-deacetyl-(-)-griseusin B except for the signals of
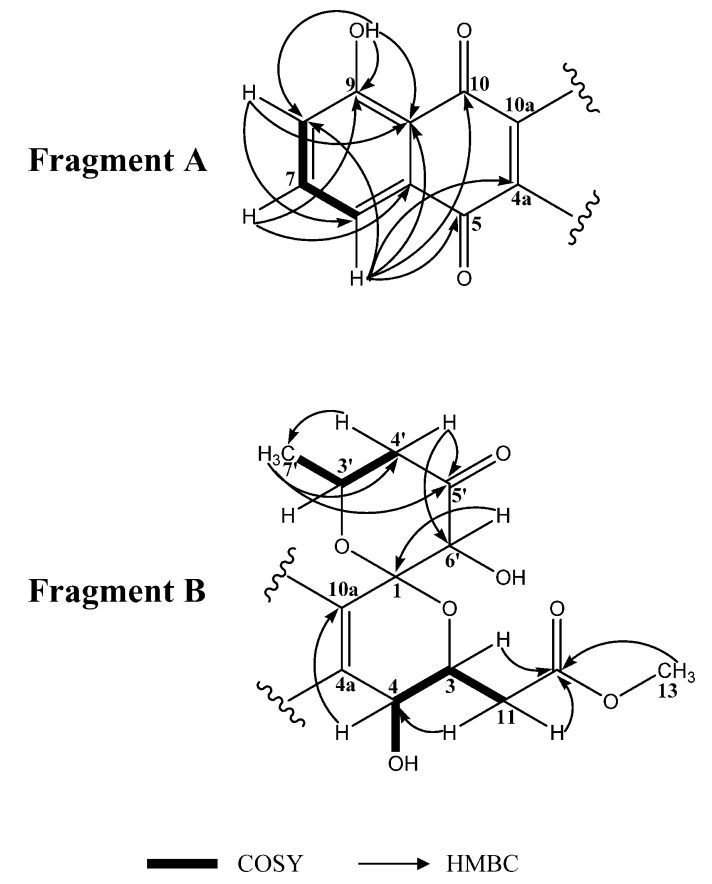

Fig. 4 Partial structures, ${ }^{1} \mathrm{H}-{ }^{1} \mathrm{H}$ COSY and key $\mathrm{HMBC}$ correlations of $\mathbf{1}$. 
Table 1 NMR spectral data for griseusin (1) in DMSO-d ${ }_{6}{ }^{a}$

\begin{tabular}{|c|c|c|c|c|}
\hline $\mathrm{C} / \mathrm{H}$ no. & ${ }^{1} \mathrm{H}(\delta)$ & ${ }^{13} \mathrm{C}(\delta)$ & ${ }^{1} \mathrm{H}-{ }^{1} \mathrm{H}$ COSY & $\mathrm{HMBC}$ \\
\hline 1 & & $100.2 \mathrm{~s}$ & & \\
\hline 3 & $4.31,1 \mathrm{H}, \mathrm{m}$ & $67.9 \mathrm{~d}$ & $\mathrm{H}-4, \mathrm{H}-11$ & C-12 \\
\hline 4 & $4.45,1 \mathrm{H}, \mathrm{d}, J=9.5$ & $58.5 d$ & $\mathrm{H}-3,4-\mathrm{OH}$ & C-10a \\
\hline $4 a$ & & $136.8 \mathrm{~s}$ & & \\
\hline 5 & & $182.0 \mathrm{~s}$ & & \\
\hline $5 a$ & & $131.5 \mathrm{~s}$ & & \\
\hline 6 & $7.57,1 \mathrm{H}, \mathrm{d}, J=7.4$ & $118.5 d$ & $\mathrm{H}-7$ & C-4a, C-5, C-8, C-9a, C-10 \\
\hline 7 & $7.78,1 \mathrm{H}, \mathrm{t}, J=8.1,7.4$ & $137.0 \mathrm{~d}$ & $\mathrm{H}-6, \mathrm{H}-8$ & C-5a, C-9 \\
\hline 8 & $7.38,1 \mathrm{H}, \mathrm{d}, J=8.1$ & $124.6 \mathrm{~d}$ & $\mathrm{H}-7$ & C-6, C-9a \\
\hline 9 & & $160.5 \mathrm{~s}$ & & \\
\hline $9 a$ & & $114.9 \mathrm{~s}$ & & \\
\hline 10 & & $187.8 \mathrm{~s}$ & & \\
\hline $10 a$ & & $145.3 \mathrm{~s}$ & & \\
\hline $11 a$ & $2.81,1 \mathrm{H}, \mathrm{d}, J=3.7$ & $34.7 t$ & $\mathrm{H}-3$ & C-4, C-12 \\
\hline $11 b$ & $2.69,1 \mathrm{H}, \mathrm{d}, J=8.8$ & & & \\
\hline 12 & & $171.0 \mathrm{~s}$ & & \\
\hline 13 & $3.62,3 \mathrm{H}, \mathrm{s}$ & $51.5 q$ & & $\mathrm{C}-12$ \\
\hline $3^{\prime}$ & $4.28,1 \mathrm{H}, \mathrm{m}$ & $67.5 \mathrm{~d}$ & $\mathrm{H}-4^{\prime}, \mathrm{H}-7^{\prime}$ & \\
\hline $4^{\prime} a$ & $2.59,1 \mathrm{H}, \mathrm{d}, J=13.2$ & $47.7 t$ & $\mathrm{H}-3^{\prime}$ & $C-5^{\prime}, C-6^{\prime}, C-7^{\prime}$ \\
\hline $4^{\prime} \mathrm{b}$ & $2.42,1 \mathrm{H}, \mathrm{d}, J=14.0$ & & & \\
\hline $5^{\prime}$ & & $203.7 \mathrm{~s}$ & & \\
\hline $6^{\prime}$ & $5.13,1 \mathrm{H}, \mathrm{s}$ & $76.3 d$ & & $\mathrm{C}-1^{\prime}$ \\
\hline $7^{\prime}$ & $1.25,3 \mathrm{H}, \mathrm{d}, J=5.9$ & $21.1 \mathrm{q}$ & $\mathrm{H}-3^{\prime}$ & $C-4^{\prime}, C-5^{\prime}$ \\
\hline $4-\mathrm{OH}$ & $4.98,1 \mathrm{H}, \mathrm{d}, J=9.5$ & & $\mathrm{H}-4$ & \\
\hline $9-\mathrm{OH}$ & $11.83,1 \mathrm{H}, \mathrm{s}$ & & & C-8, C-9, C-9a \\
\hline $6^{\prime}-\mathrm{OH}^{\mathrm{b}}$ & $3.35,1 \mathrm{H}, \mathrm{s}$ & & & \\
\hline
\end{tabular}

${ }^{a}$ The spectra were recorded on a Bruker $500 \mathrm{NMR}$ instrument at $500 \mathrm{MHz}$ for ${ }^{1} \mathrm{H}$ and $125 \mathrm{MHz}$ for ${ }^{13} \mathrm{C}, \delta$ in ppm, $J$ in $\mathrm{Hz}$. The solvent signals (2.50 ppm for ${ }^{1} \mathrm{H}-\mathrm{NMR}$, and $39.5 \mathrm{ppm}$ for ${ }^{13} \mathrm{C}-\mathrm{NMR}$ ) were used as reference. ${ }^{\mathrm{b}}$ Overlap under $\mathrm{H}_{2} \mathrm{O}$ signal.

cyclohexanone carbonyl at $\mathrm{C}-5^{\prime}$, hydroxyl at $\mathrm{C}-4$ and methoxy at $\mathrm{C}-13$. Thus, the structure of $\mathbf{1}$ was elucidated as $5^{\prime}$-one-4-hydroxy-12-methoxygriseusin $\mathrm{B}$, which we named griseusin D (Fig. 1). The unambiguous assignment of the ${ }^{1} \mathrm{H}$ and ${ }^{13} \mathrm{C}$ chemical shifts was achieved based on $2 \mathrm{D}$ NMR data analysis including ${ }^{1} \mathrm{H}-{ }^{1} \mathrm{H}$ COSY, HSQC, and HMBC as detailed in Table 1.

The stereochemistry of $\mathbf{1}$ was established by analyses of NOESY. The relative stereochemistry on C-3, C-4, C-3', C$6^{\prime}$ was assigned on the basis of the NOE correlations between $\mathrm{H}-3$ and $\mathrm{H}-4, \mathrm{H}-3^{\prime}$ and $\mathrm{H}-4^{\prime} \mathrm{a}$ or $\mathrm{H}-4^{\prime} \mathrm{b}, \mathrm{H}_{3}-7^{\prime}$ and $\mathrm{H}-4^{\prime} \mathrm{a}$ or $\mathrm{H}-4^{\prime} \mathrm{b}, 4-\mathrm{OH}$ and $6^{\prime}-\mathrm{OH}$ as shown in Fig. 5. Furthermore, the constitutional formula as well as the relative configuration of $\mathbf{1}$ derived from the interpretation of the NMR data was fully confirmed by single-crystal Xray determination. A perspective view of the solid state conformation was shown in Fig. 6.

Crystals of 1 were obtained from a hot $\mathrm{MeOH} / \mathrm{H}_{2} \mathrm{O}$

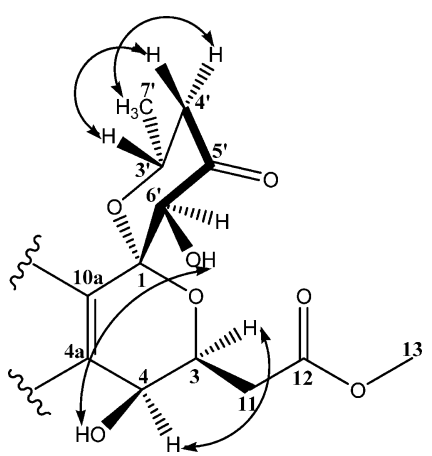

Fig. $\mathbf{5}$ The relative configuration of $\mathbf{1}$ and NOE correlation observed in NOESY spectrum (represented by double arrows).

solution. A yellow needle crystal of $0.22 \times 0.20 \times 0.16 \mathrm{~mm}$ was mounted on a glass fiber. All measurements were made on a Bruker SMART APEX CCD X-ray diffractometer 


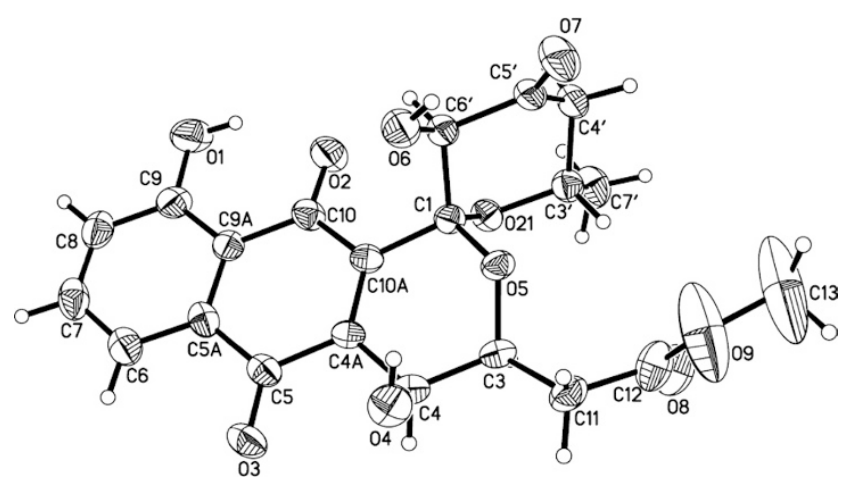

Fig. 6 Crystal structure of $\mathbf{1}$.

with graphite monochromated Mo- $\mathrm{K}_{\mathrm{a}}$ radiation. Crystal data: Empirical formula: $\mathrm{C}_{21} \mathrm{H}_{20} \mathrm{O}_{10}$; Molecular weight: 432.37; Crystal system: monoclinic; Space group: P2(1); Lattice parameters: $a=15.961(3) \AA, \quad b=7.8084(15) \AA$, $c=17.606(3) \AA$; Volume: 2087.3(7) $\AA^{3}$; $\mathrm{Z}$ value: $4 ; \mathrm{D}_{\text {calc }}$ : $1.376 \mathrm{~g} / \mathrm{cm}^{3} ; \mathrm{T}: 293 \mathrm{~K}$. The structure was solved by a direct method (SHELXS-97). Final R and wR were 0.0616 and 0.1531 for 5911 observed reflections, respectively.

1: Orange needle crystal; HRESI-MS $\mathrm{m} / \mathrm{z} 455.0999$ $\left[\mathrm{M}+\mathrm{Na}, \mathrm{C}_{21} \mathrm{H}_{20} \mathrm{O}_{10} \mathrm{Na}\right]^{+}, 431.1025\left[\mathrm{M}-\mathrm{H}, \mathrm{C}_{21} \mathrm{H}_{19} \mathrm{O}_{10}\right]^{-}$; $[\alpha]_{\mathrm{D}}^{26}-68(c 0.005, \mathrm{MeOH}) ; \mathrm{UV} \lambda_{\max }^{\mathrm{MeOH}} \mathrm{nm}(\log \varepsilon) 213$ (3.51), 256 (3.74); ${ }^{1} \mathrm{H}$ - and ${ }^{13} \mathrm{C}-\mathrm{NMR}$ data, see Table 1.

1 displayed strong cytotoxicity against human leukemia cells (HL60) and modest cytotoxicity against human lung denocarcinoma cell lines (AGZY) with $\mathrm{IC}_{50}$ values of 0.23 and $19.6 \mu \mathrm{g} / \mathrm{ml}$, respectively. It also exhibited weak antifungal activity against Alternaria alternate with MIC of $140 \mu \mathrm{g} / \mathrm{ml}$.
Acknowledgement This work was financially supported by the National Natural Science Foundation of China (Grant Nos. 20362009, 20462008, 30460022, 30660004), Ministry of Science and Technology, PR China (Grant No. 2006BAE01A01-9) and Yunnan Provincial Natural Science Foundation (Grant Nos. 2004C0002Z, 2006C0004M).

\section{References}

1. Brimble MA, Duncalf LJ, Nairn MR. Pyranonaphthoquinone antibiotics-isolation, structure and biological activity. Nat Prod Rep 16: 267-281 (1999)

2. Tsuji N, Kobayashi M, Wakisaka Y, Kawamura Y, Mayama M, Matsumoto K. New antibiotics, griseusins A and B. Isolation and characterization. J Antibiot 29: 7-9 (1976)

3. Tsuji N, Kobayashi M, Terui Y, Tori K. The structures of griseusins $\mathrm{A}$ and $\mathrm{B}$, new isochromanquinone antibiotics. Tetrahedron 32: 2207-2210 (1976)

4. Tsuji N, Kamigauchi T, Nakai H, Shiro M. X-Ray analysis of dibromogriseusin A, revised absolute configuration of griseusins. Tetrahedron Lett 24: 389-390 (1983)

5. Maruyama $M$, Nishida $C$, Takahashi $Y$, Naganawa $H$, Hamada, M, Takeuchi T. 3'-O- $\alpha$-D-Forosaminyl-(+)-griseusin A from Streptomyces griseus. J Antibiot 47: 952-954 (1994)

6. Igarashi $\mathrm{M}$, Chen $\mathrm{W}$, Tsuchida $\mathrm{T}$, Umekita M, Sawa T, Naganawa H, Hamada M, Takeuchi T. 4'-Deacetyl-(-) griseusins $\mathrm{A}$ and $\mathrm{B}$, new naphthoquinone antibiotics from an Actinomycete. J Antibiot 48: 1502-1505 (1995)

7. Li X, Zheng Y, Sattler I, Lin W. Griseusin C, a novel quinone derivative from a marine-derived fungus Penicillium sp. Arch Pharm Res 29: 942-945 (2006) 